\title{
Kebijakan Hukum Pidana dalam Pengaturan dan Penanggulangan Ujaran Kebencian (Hate Speech) di Media Sosial
}

\author{
Ahmad Faizal Azhar ${ }^{*}$, Eko Soponyono² \\ 1Program Studi Magister IImu Hukum, Fakultas Hukum, Universitas Diponegoro \\ 2Fakultas Hukum, Universitas Diponegoro \\ *Achmadfaisalazhar@gmail.com
}

\begin{abstract}
The development of technology and information regarding freedom of determination and delivery of information in Indonesia, agreeing to individuals or groups such as Ethnic, Religious, Racial, Intergroup. The purpose of this study is to discuss the Criminal Policy in the Arrangement and Management of Hate Speech (Hate Speech) in the current and future social media. Renewal legal policies for testing new standards in the Criminal Code; Act Number 1 of 1946; Law Number 1 / PNPS of 1965; Law Number 40 of 1999; Law Number 32 Year 2002; Law Number 40 Year 2008; Law No. 19 of 2016 still has juridical weaknesses and its policies are not yet systemic, and have not been able to optimally address freedom of speech distribution through the legal system of the court. The KUHP concept that is being initiated has accommodated all the shortcomings needed in the current regulations as a regulation and overcoming hate speech.
\end{abstract}

Keywords: Criminal Law Policy; In the Arrangement and Management of Hate Speeches; on Social Media.

\begin{abstract}
ABSTRAK
Perkembangan teknologi dan informatika berdampak pada kebebasan berpendapat dan penyampaian informasi di Indonesia seringkali meresahkan individu maupun kelompok seperti Suku, Agama, Ras, Antar Golongan. Tujuan penulisan ini membahas Kebijakan Hukum Pidana Dalam Pengaturan Dan Penanggulangan Ujaran Kebencian (Hate Speech) di Media Sosial masa saat ini dan masa yang akan datang. Kebijakan hukum pidana penyebaran ujaran kebencian dalam KUHP; UU Nomor 1 Tahun 1946; UU Nomor 1/PNPS Tahun 1965; UU Nomor 40 Tahun 1999; UU Nomor 32 Tahun 2002; UU Nomor 40 Tahun 2008; UU Nomor 19 Tahun 2016 masih banyak terdapat kelemahan yuridis dan dari kebijakannya belum sistemik, dan belum mampu maksimal dalam menaggulangi kejahatan penyebaran ujaran kebencian melalui sarana sistem hukum pidana. Pada konsep KUHP yang sedang digagas telah mengakomodir seluruh kekurangan yang terdapat dalam peraturan perundang-undangan saat ini sebagai pengaturan dan penanggulangan ujaran kebencian.
\end{abstract}

Kata Kunci : Kebijakan Hukum Pidana; dalam Pengaturan dan Penanggulangan Ujaran Kebencian; di Media Sosial.

\section{A. PENDAHULUAN}

Perkembangan teknologi komputer dan internet memberikan implikasi-implikasi dan dampak yang sangat signifikan terhadap pengaturan atau pembentukan regulasi dalam ruang siber dan hukum siber serta terhadap perkembangan kejahatan dalam 
Jurnal Pembangunan Hukum Indonesia

Volume 2, Nomor 2, Tahun 2020
Program Studi Magister Ilmu Hukum Fakultas Hukum Universitas Diponegoro dunia maya cyberspace atau cyber crimes (Sitompul, 2012). Meski penggunaan internet secara meluas ini pada satu sisi membawa perubahan yang positif pada bidang kehidupan baik di bidang politik, sosial, ekonomi dan sebagainya, Namun disisi lain menimbulkan perubahan paradigma dalam studi mengenai kejahatan terutama kejahatan yang berhubungan dengan teknologi (Raharjo, 2002).

Teknologi selain membawa dampak positif, juga membawa pengaruh negatif. Bahkan menurut data Direktorat Reserse Kriminal Khusus Polda Metro Jaya menangani 1.627 kasus pidana sepanjang 2016. Dari 1.627 kasus tersebut,cyber crime jadi kasus dengan jumlah tertinggi, yakni 1.207 kasus (Amelia, 2016).

Secara umum yang dimaksud kejahatan komputer atau kejahatan di dunia cyber (cybercrime) adalah "Upaya memasuki dan atau menggunakan fasilitas komputer atau jaringan komputer tanpa ijin dan dengan melawan hukum dengan atau tanpa menyebabkan perubahan dan atau kerusakan pada fasilitas komputer yang dimasuki atau digunakan tersebut (Goodall, 2013).

Istilah cyber crime saat ini merujuk pada suatu tindakan kejahatan yang berhubungan dengan dunia maya (cyberspace) dan tindakan kejahatan yang menggunakan komputer (Arief, 2005). Barda Nawawi Arief menunjuk pada kerangka (sistemik) Draft Convention on Cyber Crime dari Dewan Eropa (Draft No. 25, Desember 2000). Beliau menyamakan peristilahan antara keduanya dengan memberikan definisi cybercrime sebagai "crime related to technology, computers and the internet" atau secara sederhana berarti kejahatan yang berhubungan dengan teknologi, komputer dan internet (Mansur, \& Gultom, 2009).

Suatu hal yang harus dipahami betul, bahwa hukum pidana saat ini adalah apa yang disampaikan oleh Jan Remmelink dalam setiap delik apa yang berfungsi dan dianggap sebagai unsur pembentuk selain perilaku manusia juga berbuat dan tidak berbuat, sikap batin seseorang betapapun immoral ataupun tercelanya bagi masyarakat, tidaklah penting. Saat ini hukum pidana masih terfokus pada tindakan (daadstrafrecht). Dalam hal ini, bukan saja kualifikasi individuyang berbahaya secara sosial yang menjadi fokus utama, melainkan juga perbuatan atau tindakan yang dilakukannya (Arief, 2006).

Beberapa kasus yang berkaitan dengan kejahatan, konflik sosial, pertentangan, perpecahan di masyarakat seringkali berlatar belakang dari kebencian, sikap bias atau prasangka (prejudice) pada kelompok tertentu (yang berbeda) yang umumnya dianggap sebagai ancaman (Supanto, 2016). Istilah hate crimes pada awalnya muncul di dalam sistem hukum Amerika Serikat. Istilah ini kemudian juga berkembang di Eropa dan Inggris. Di mana awalnya, dalam sistem hukum yang berlaku di negara-negara tersebut istilah hate crimes merujuk pada perbuatan-perbuatan yang dikualifikasikan sebagai tindak pidana racially aggravatedoffences (Jacobs, \& Henry, 1996). 
Jurnal Pembangunan Hukum Indonesia

Volume 2, Nomor 2, Tahun 2020
Program Studi Magister Ilmu Hukum Fakultas Hukum Universitas Diponegoro
Sekalipun pustaka hukum maupun peraturan perundang-undangan di berbagai Negara mendefinisikan atau mengkategorikan kejahatan yang digambarkan di atas dengan cara yang berbeda-beda, umumnya hate crimes didefinisikan sebagai "berbagai jenis kejahatan atau perbuatan pidana yang dilakukan terhadap orang atau kelompok orang ataupun harta bendanya dengan latar belakang/motif kebencian atau prejudice pelaku terhadap korbannya semata-mata karena korban merupakan anggota kelompok (ras, etnis, kebangsaan, keagamaan, difabilitas, orientasi seksual (Grande, 2006).

Sementara itu, ujaran kebencian menurut Cohen-Almagor (Elliot et al, 2016), adalah sebagai berikut: "Hate speech is defined as a bias-motivated, hostile, malicious speech aimed at a person or a group of people because of some of their actual or perceived innate characteristics. It expresses discriminatory, intimidating, disapproving, antagonistic, and/or prejudicial attitudes toward those characteristics, which include gender, race, religion, ethnicity, color, national origin, disability, or sexual orientation. Hate speech is aimed to injure, dehumanize, harass, intimidate, debase, degrade, and victimize the targeted groups and to foment insensitivity and brutality against them."

"Ujaran yang mendorong kebencian didefinisikan sebagai ujaran yang bermotif bias, bermusuhan, dan jahat yang ditujukan kepada seseorang atau sekelompok orang karena beberapa dari mereka yang sebenarnya atau yang dirasakan karakteristik bawaan. Ini mengekspresikan diskriminatif, mengintimidasi, tidak menyetujui, sikap antagonistik, dan atau prasangka terhadap karakteristik tersebut, yang termasuk jenis kelamin, ras, agama, etnis, warna kulit, asal kebangsaan, kecacatan, atau orientasi seksual. Perkataan yang mendorong kebencian ditujukan untuk melukai, merendahkan manusia, melecehkan, serta mengintimidasi, merendahkan, menurunkan, dan mengorbankan kelompok sasaran dan menggerakkan ketidak sensitifan dan kebrutalan terhadap mereka (Verkhovsky, 2016).

Sistem pemidanaan di dalam KUHP saat ini sebagai bangunan induk, tidak secara eksplisit memberi ruang pada penanggulangan tindak pidana penyebaran ujaran kebencian dalam dunia maya, terutama kaitannya dengan tindak pidana, pertanggungjawaban pidana dan juga penjatuhan pidana. Hal ini merupakan keharusan bagi negara sesuai amanah dari dokumen Kongres PBB X/2000 yang memberikan catatan salah satunya menyebutkan bahwa penanggulangan Cyber Crime memerlukan keahlian khusus, prosedur investigasi dan kekuatan/dasar hukum yang mungkin tidak tersedia pada aparat penegak hukum yang bersangkutan (Arief, 2008).

Apalagi zaman saat ini pidana penyebaran ujaran kebencian tidak dilakukan hanya oleh seorang, melainkan suatu korporasi yang sudah terstruktur dan memiliki visi misi yang kuat. Suatu hal 
Jurnal Pembangunan Hukum Indonesia

Volume 2, Nomor 2, Tahun 2020
Program Studi Magister Ilmu Hukum Fakultas Hukum Universitas Diponegoro yang harus dipahami betul, bahwa hukum pidana saat ini adalah apa yang disampaikan oleh Jan Remmelink. Dalam setiap delik apa yang berfungsi dan dianggap sebagai unsur pembentuk selain perilaku manusia juga berbuat dan tidak berbuat, sikap batin seseorang betapapun immoral ataupun tercelanya bagi masyarakat, tidaklah penting. Saat ini hukum pidana masih terfokus pada tindakan atau daadstrafrecht .

Sementara itu dalam mewujudkan ide pembentukan hukum baru atau peraturan hukum pidana yang akan datang (ius constituendum) terutama peraturan perundang-undangan mengenai perlindungan terhadap kepentingan hukum negara khususnya penanggulangan persiapan sebagai delik yang dapat dirumuskan/diformulasikan secara lebih baik sesuai tujuan utama dari pemidanaan yaitu melindungi masyarakat secara keseluruhan. Kebijakan formulasi/legislatif adalah salah satu dari 3 (tiga) rangkaian proses kebijakan hukum pidana. Sedangkan substansi/masalah pokok dalam kebijakan formulasi terdiri (Arief, 2016) : masalah tindak pidana; masalah kesalahan; dan masalah pidana (pemidanaan).

Dalam hal ini, bukan saja kualifikasi individu yang berbahaya secara sosial yang menjadi fokus utama, melainkan juga perbuatan atau tindakan yang dilakukannya. Berdasarkan uraian diatas, maka penelitian ini bertujuan untuk meneliti lebih lanjut bagaimana kebijakan hukum pidana dalam pengaturan dan penanggulangan tindak pidana penyebaran ujaran kebencian (hate speech) di media sosial masa saat ini dan bagaimana kebijakan hukum pidana dalam pengaturan dan penanggulangan tindak pidana penyebaran ujaran kebencian (hate speech) di media sosial masa yang akan datang?

Beberapa penelitian sebelumnya membahas mengenai ujaran kebencian yang di atur dalam Peraturan Kapolri Nomor. SE/6/X/2015 tentang Penanganan Ucapan Kebencian (Mangantibe, 2016), disamping itu mengkaji hal yang sama tetapi dalam perspektif yang berbeda dalam hal ini adalah perspektif Hak Asasi Manusia (Anam,\& Hafiz, 2015). Erik Bleich meneliti pengaturan dan penegakan ketentuan terhadap hasutan untuk kebencian rasial, dan kejahatan yang dimotivasi oleh isu sara di Eropa Barat dan Amerika Serikat (Bleich, 2011).

Penelitian yang lain membahas penafsiran hasutan untuk kebencian di Slovakia dengan tiga cara yang berbeda tetapi saling melengkapi: hasutan untuk kekerasan; hasutan untuk melakukan diskriminasi; dan hasutan untuk merendahkan martabat manusia (Pejchal, 2018). Penanggungan ujaran kebencian melalui kinerja aparat penegak hukum dalam hal ini kepolisian (Monica, 2017), selain itu membahas mengenai pemberian sanksi pidana pencemaran nama baik berdasarkan UndangUndang Nomor 19 Tahun 2016 tentang Informasi dan Transaksi Elektronik (Siddiq, 2017) sehingga dalam artikel ini berfokus kepada kebijakan formulasi penanggulangan tindak pidana penyebaran ujaran 
Jurnal Pembangunan Hukum Indonesia

Volume 2, Nomor 2, Tahun 2020
Program Studi Magister Ilmu Hukum Fakultas Hukum Universitas Diponegoro kebencian yang ada pada saat ini dan di masa yang akan datang.

\section{B. METODE PENELITIAN}

Metode penelitian yang digunakan dalam penulisan karya ilmiah ini adalah yuridis normatif yaitu dengan cara pendekatan perundang-undangan. Metode penelitian yuridis normatif adalah penelitian hukum dari perspektif internal dengan objek penelitiannya adalah norma hukum (Diantha, 2016).

Sumber penelitian karya ilmiah ini menggunakan data yang diperoleh dengan cara menelaah bahan hukum primer yaitu peraturan perundang-undangan dan bahan hukum sekunder berupa doktrin atau teori yang diperoleh dari literatur hukum dan penelitian ilmiah. Selanjutnya akan dikaitkan dengan permasalahan yang akan dibahas yaitu Kebijakan Hukum Pidana dalam Pengaturan dan Penanggulangan Ujaran Kebencian (Hate Speech) di Media Sosial.

\section{HASIL DAN PEMBAHASAN}

1. Kebijakan Hukum Pidana dalam Pengaturan dan Penanggulangan Ujaran Kebencian (Hate Speech) di Media Sosial Saat Ini.

Ujaran Kebencian (Hate Speech) di dalam definisi hukum adalah perkataan, perilaku, tulisan, ataupun pertunjukan yang dilarang karena dapat memicu terjadinya tindakan konflik social, kekerasan dan sikap prasangka baik dari pihak pelaku pernyataan tersebut ataupun korban dari tindakan tersebut (Marpaung, 2010).

Website yang menggunakan atau menerapkan Ujaran Kebencian (Hate Speech) ini disebut (Hate Site). Situs ini mayoritas menggunakan Forum Internet dan Berita untuk mempertegas suatu sudut pandang tertentu. Kebanyakan negara diseluruh dunia memiliki peraturan perundangundang yang mengatur tentang Ujaran Kebencian (Hate Speech), di Indonesia terdapat pengaturan dalam Pasal-Pasal yang mengatur tindakan tentang Ujaran Kebencian (Hate Speech) terhadap seseorang, kelompok ataupun lembaga (Ali, 2010).

Penyebarluasan, cara penyampaian gambar atau benda sebagaimana yang dimaksud dalam pasal ini dapat dilakukan dengan berbagai macam cara misalnya menyiarkan atau mempertunjukkan gambar atau benda melalui media elektronik (televisi/radio), media cetak (koran, tabloid, majalah), ataupun media lainnya termasuk di dalamnya adalah internet (Brown, 2017).

Terlihat bahwa di dalam KUHP Pasal 310 memuat tindak pidana yang dinamakan menista (smaad); kemudian Pasal 311 memuat tindak pidana yang dinamakan memfitnah (laster) tanpa memakai kata menghina. Kemudian terdapat dalam Pasal 315 memuat suatu tindak pidana yang dinamakan penghinaan bersahaja (eenvoudig beleediging), dan yang dirumuskan sebagai setiap penghinaan dengan sengaja (elke opzettelihke beleediging) yang tidak bersifat menista. Tampaklah bahwa penistaan adalah 
Jurnal Pembangunan Hukum Indonesia

Volume 2, Nomor 2, Tahun 2020
Program Studi Magister Ilmu Hukum Fakultas Hukum Universitas Diponegoro suatu pengkhususan dengan penghinaan. Terlihat bahwa penistaan adalah bagian dari penghinaan (Dahri, 2017).

Beberapa pasal tersebut juga memiliki keterkaitan dengan kemajuan teknologi informasi yang tumbuh begitu pesatnya, maka penyiaran atau cara penyampaian gambar atau benda sebagaimana yang dimaksud dalam pasal di atas dapat dilakukan dengan berbagai macam cara pula, misalnya menyiarkan atau mempertunjukkan gambar atau benda melalui media elektronik (televisi/radio), media cetak (koran, tabloid, majalah), ataupun media lainnya termasuk di dalamnya adalah internet (Nahak, 2017).

Adapula pengaturan lain yaitu dalam UndangUndang di Luar KUHP, seperti Undang-Undang Nomor 11 Tahun 2008 sebagaimana telah diubah menjadi Undang-Undang Nomor 19 Tahun 2016 tentang Informasi dan Transaksi Elektronik, UndanUndang Nomor 40 Tahun 2008 tentang Penghapusan Diskriminasi dan Ras, pasal-pasal yang berkaitan langsung dengan tindak pidana penyebaran ujaran kebencian adalah Pasal 27 ayat (3) Pasal 28 ayat (1) dan (2), Pasal 45 ayat (1) dan ayat (2), Pasal 52 ayat (4).

Pasal 27 (1) "Setiap Orang dengan sengaja dan tanpa hak mendistribusikan dan/atau mentransmisikan dan/atau membuat dapat diaksesnya Informasi Elektronik dan/atau Dokumen Elektronik yang memiliki muatan penghinaan dan/atau pencemaran nama baik".
Pasal 28 (1) "Setiap Orang dengan sengaja dan tanpa hak menyebarkan berita bohong dan menyesatkan yang mengakibatkan kerugian konsumen dalam Transaksi Elektronik". (2) "Setiap Orang dengan sengaja dan tanpa hak menyebarkan informasi yang ditujukan untuk menimbulkan rasa kebencian atau permusuhan individu dan/atau kelompok masyarakat tertentu berdasarkan atas suku, agama, ras, dan antargolongan (SARA)".

Pasal 45 (4) "Setiap Orang yang dengan sengaja dan tanpa hak mendistribusikan dan/atau mentransmisikan dan/atau membuat dapat diaksesnya Informasi Elektronik dan/atau Dokumen Elektronik yang memiliki muatan penghinaan dan/atau pencemaran nama baik sebagaimana dimaksud dalam Pasal 27 ayat (3) dipidana dengan pidana penjara paling lama 4 (empat) tahun dan/atau denda paling banyak Rp750.000.000,00 (tujuh ratus lima puluh juta rupiah)".

Pasal 45A (1) "Setiap Orang yang dengan sengaja dan tanpa hakmenyebarkan berita bohong dan menyesatkan yang mengakibatkan kerugian konsumen dalam Transaksi Elektronik sebagaimana dimaksud dalam Pasal 28 ayat (1) dipidana dengan pidana penjara paling lama 6 (enam) tahun dan/atau denda paling banyak Rp1.000.000.000,00 (satu miliar rupiah)". (2) "Setiap Orang yang dengan sengaja dan tanpa hak menyebarkan informasi yang ditujukan untuk menimbulkan rasa kebencian atau permusuhan individu dan/atau kelompok masyarakat tertentu berdasarkan atas suku, agama, ras, dan 
Jurnal Pembangunan Hukum Indonesia

Volume 2, Nomor 2, Tahun 2020
Program Studi Magister Ilmu Hukum Fakultas Hukum Universitas Diponegoro antar golongan (SARA) sebagaimana dimaksud dalamPasal 28 ayat (2) dipidana dengan pidana penjarapaling lama 6 (enam) tahun dan/atau denda paling banyak Rp1.000.000.000,00; satu miliar rupiah (Chazawi, \& Ferdian. 2011).

Berdasarkan unsur-unsur tindak pidana yang ada dalam rumusan pasal-pasal di atas, dapatlah diamati bahwa UU-ITE tersebut tidak menyebutkan atau membedakan kualifikasi deliknya sebagai kejahatan atau pelanggaran, Tentu ini membawa konsekuensi yuridis karena KUHP (WvS) masih mengikuti dan membedakan kualifikasi delik antara kejahatan dan pelanggaran, sehingga undangundang ini tetap harus mengacu pada ketentuan induknya.

Beberapa Undang-Undang yang mengatur penyebaran ujaran kebencian mengandung beberapa masalah yuridis yaitu Pasal 156 ayat (1) KUHP Barang siapa di muka umum menyatakan permusuhan, kebencian atau meremehkan (minacthing) terhadap suatu atau beberapa golongan rakyat Indonesia, diancam dengan pidana penjara maksimum empat (4) tahun atau pidana denda paling banyak empat ribu lima ratus rupiah. Dalam pasal tersebut adanya suatu keterbatasan jurisdiksi; tidak ada ketentuan tentang subjek dan pertanggungjawaban pidana (PJP) korporasi; UU Nomor 1/PNPS Tahun 1965 tentang Penodaan Agama Pasal 1 Setiap orang dilarang dengan sengaja di muka umum menceritakan, menganjurkan atau mengusahakan dukungan umum, untuk melakukan penafsiran tentang sesuatu agama yang dianut di Indonesia atau melakukan kegiatankegiatan keagamaan yang menyerupai kegiatankegiatan keagamaan dari agama itu; penafsiran dan kegiatan mana menyimpang dari pokok-pokok ajaran agama itu. (Tidak terdapat kualifikasi delik; Tidak memuat subjek hukum dan PJP selain perseorangan; Hanya mengenal pidana tunggal) (Nurdin, 2017);

UU Nomor 40 Tahun 1999 Tentang Pers pasal Pasal 18 ayat (1) Setiap orang yang secara melawan hukum dengan sengaja melakukan tindakan yang berakibat menghambat atau menghalangi pelaksanaan ketentuan Pasal 4 ayat (2) dan ayat (3) dipidana dengan pidana penjara paling lama 2 (dua) tahun atau denda paling banyak Rp.500.000.000,00 (lima ratus juta rupiah). Dalam pasal tersebut Tidak disertakan penentuan kualifikasi delik Kejahatan atau Pelanggaran; tidak ada pidana tambahan bagi korporasi yang melanggar); UU Nomor 40 Tahun 2008 tentang Penghapusan Diskriminasi dan Ras (Tidak terdapat kualifikasi delik; Denda bagi korporasi yang tinggi tidak diimbang dengan perubahan/aturan khusus ttg "pidana pengganti" denda (yg menurut Psl. 30 KUHP, pid. Penggantinya hanya kurungan max. 6 bln.); UU Nomor 19 Tahun 2016 tentang Informasi dan Transaksi Elektronik (tidak ada kualifikasi delik; Pidana denda cukup tinggi: max 12 M (untuk KORPORASI bisa $20 \mathrm{M}$ ), tetapi tidak ada perubahan/aturan khusus tentang "pidana pengganti" denda (yang menurut Psl. 30 KUHP, pid. Penggantinya hanya kurungan max. 6 bln.); Aturan PJP Korporasinya hanya ada dalam "Penjelasan Psl. 
Jurnal Pembangunan Hukum Indonesia

Volume 2, Nomor 2, Tahun 2020
Program Studi Magister Ilmu Hukum Fakultas Hukum Universitas Diponegoro
52 ayat 4" ; Tidak ada ketentuan khusus pidana pengganti denda untuk Korporasi; Formulasi Psl. 52sangat sembrono \& tidak jelas).

2. Kebijakan Hukum Pidana dalam Pengaturan dan Penanggulangan Ujaran Kebencian (Hate Speech) di Media Sosial pada masa yang akan datang.

Kebijakan hukum pidana tidak dapat dilepaskan dari ide pembangunan sistem hukum nasional yang berlandaskan Pancasila sebagai nilai kehidupan yang dicita-citakan oleh bangsa Indonesia. Hal ini mengandung arti bahwa seharusnya pembaharuan KUHP seyogyanya juga dilatarbelakangi oleh sumber-sumber yang beorientasi pada ide dasar Pancasila yang didalamnya mengandung konsep nilai Ketuhanan, Kemanusiaan, Kebangsaan, Demokrasi dan Keadilan Sosial. Dalam laporan simposium Pembaharuan Hukum Pidana Nasional yang diadakan di Semarang bahwa Pembaharuan Hukum Pidana nasional pada hakekatnya adalah usaha yang langsung menyangkut harkat dan martabat bangsa dan negara Indonesia serta merupakan sarana pokok bagi terciptanya tujuan nasional (Arief, 2008). Untuk itu dalam mewujudkan suatu pembaharuan hukum pidana Nasional terutama dalam Induk KUHP perlu adanya suatu Konsep/gagasan dalam merumuskan Rancangan KUHP baru yang bisa menjangkau kejahatan khususnya Kejahatan yang berhubungan dengan Ujaran Kebencian (Hate Speech) di Media Sosial yang akan datang terutama yang termuat dalam Konsep KUHP Indonesia.

Pasal dalam Konsep KUHP terkait tindak pidana penyebaran ujaran kebencian :

Pasal 209, Penghinaan Ideologi Negara Pancasila;

- Pasal 238 (1), Penghinaan di muka umum terhadap presiden dan wakil presiden;

- Pasal 239; menyiarkan, mempertunjukkan, atau menempelkan tulisan atau gambar sehingga terlihat oleh umum, atau memperdengarkan rekaman sehingga terdengar oleh umum, atau menyebarluaskan dengan sarana teknologi informasi, yang berisi penghinaan terhadap Presiden atau Wakil Presiden dengan maksud agar isi penghinaan diketahui atau lebih diketahui umum(Tampi, 2016).

- Pasal 244; di muka umum menghina kepala negara sahabat yang sedang menjalankan tugas kenegaraan dinegara Republik Indonesia.

- Pasal 245; Setiap Orang yang di muka umum menghina wakil dari negara sahabat yang bertugas di negara Republik Indonesia

- $\quad$ Pasal 246 (1) ; Jika Pasal 244 dilakukan di dalam dunia maya.

- Pasal 246 (2); Jangka waktu pengulangan pada huruf (1) adalah 2 tahun

- Pasal 257 (a); mencoret, menulisi, menggambar atau menggambari, atau membuat rusak Lambang Negara dengan maksud menodai, 
Jurnal Pembangunan Hukum Indonesia

Volume 2, Nomor 2, Tahun 2020
Program Studi Magister Ilmu Hukum Fakultas Hukum Universitas Diponegoro menghina, atau merendahkan kehormatan Lambang Negara;

- Pasal 258; merubah lagu kebangsaan dengan nada, irama, kata-kata dan dan gubahan lain dengan maksud untuk menghina atau merendahkan kehormatan Lagu Kebangsaan; memperdengarkan, menyanyikan, ataupun menyebarluaskan hasil ubahan Lagu Kebangsaan dengan maksud untuk tujuan komersial; atau menggunakan Lagu Kebangsaan untuk iklan dengan maksud untuk tujuan komersial.

- Pasal 259; di muka umum melakukan penghinaan terhadap pemerintah yang sah yang berakibat terjadinya keonaran dalam masyarakat.

- Pasal 260; menyiarkan, mempertunjukkan, atau menempelkan tulisan atau gambar sehingga terlihat oleh umum, memperdengarkan rekaman sehingga terdengar oleh umum, atau menyebarluaskan dengan sarana teknologi informasi yang berisi penghinaan terhadap pemerintah yang sah dengan maksud agar isi penghinaan diketahui umum.

- $\quad$ Pasal 261; melakukan penghinaan terhadap satu atau beberapa golongan penduduk Indonesia berdasarkan ras, kebangsaan, etnis, warna kulit, dan agama, atau terhadap kelompok berdasarkan jenis kelamin, umur, disabilitas mental, atau disabilitas fisik.

- Pasal 262 (1); menyiarkan, mempertunjukkan, atau menempelkan tulisan atau gambar sehingga terlihat oleh umum atau memperdengarkan rekaman sehingga terdengar oleh umum atau menyebarluaskan dengan sarana teknologi informasi, yang berisi pernyataan perasaan permusuhan dengan maksud agar isinya diketahui atau lebih diketahui oleh umum, terhadap satu atau beberapa golongan penduduk Indonesia yang dapat ditentukan berdasarkan ras, kebangsaan, etnik, warna kulit, dan agama, atau terhadap kelompok yang dapat ditentukan berdasarkan jenis kelamin, umur, disabilitas mental atau fisik yang berakibat timbulnya Kekerasan terhadap orang atau Barang, sementara pada ayat 2, diatur pemberatan bagi pengulangan.

- Pasal 328; di muka umum melakukan penghinaan terhadap agama di Indonesia.

- Pasal 329; menyiarkan, mempertunjukkan, menempelkan tulisan atau gambar, atau memperdengarkan suatu rekaman, termasuk menyebarluaskan melalui sarana teknologi informasi yang berisi Tindak Pidana sebagaimana dimaksud dalam Pasal 328, dengan maksud agar isi tulisan, gambar, atau rekaman tersebut diketahui atau lebih diketahui oleh umum. sementara pada ayat 2, diatur pemberatan bagi pengulangan.

- Pasal 330; menghasut dalam bentuk apapun dengan maksud meniadakan keyakinan terhadap agama yang sah dianut di Indonesia.

- Pasal 332;di muka umum melakukan penghinaan terhadap orang yang sedang 
Jurnal Pembangunan Hukum Indonesia

Volume 2, Nomor 2, Tahun 2020
Program Studi Magister Ilmu Hukum Fakultas Hukum Universitas Diponegoro menjalankan atau memimpin penyelenggaraan ibadah

- Pasal 385 (1); di muka umum dengan lisan atau tulisan menghina kekuasaan umum atau lembaga negara, ayat (2) jika mengakibatkan keonaran di masyarakat.

- Pasal 386; menyiarkan, mempertunjukkan, atau menempelkan tulisan atau gambar atau memperdengarkan rekaman, atau menyebarluaskan melalui sarana teknologi informasi yang berisi penghinaan terhadap kekuasaan umum atau lembaga negara, dengan maksud agar isi penghinaan tersebut diketahui atau lebih diketahui oleh umum.

- Pasal 484 (1); dengan lisan menyerang kehormatan atau nama baik orang lain dengan cara menuduhkan suatu hal, dengan maksud supaya hal tersebut diketahui umum

- $\quad$ Pasal 484 (2); Jika perbuatan sebagaimana dimaksud pada ayat (1) dilakukan dengan tulisan atau gambar yang disiarkan, dipertunjukkan, atau ditempelkan di tempat umum dipidana karena pencemaran tertulis

- $\quad$ Pasal 484 (3); Jika perbuatan sebagaimana dimaksud pada ayat (1) dan ayat (2) dilakukan dengan menggunakan teknologi informasi

- Pasal 485 (1); Jika Setiap Orang sebagaimana dimaksud dalam Pasal 484 diberi kesempatan membuktikan kebenaran hal yang dituduhkan tetapi tidak dapat membuktikannya dipidana karena fitnah
- $\quad$ Pasal 487; Penghinaan ringan; Penghinaan yang tidak bersifat pencemaran atau pencemaran tertulis yang dilakukan terhadap seseorang baik di muka umum dengan lisan atau tulisan, maupun di muka orang yang dihina tersebut secara lisan atau dengan perbuatan atau dengan tulisan yang dikirimkan atau diterimakan kepadanya

- Pasal 488; Ketentuan pidana sebagaimana dimaksud dalam Pasal 484 sampai dengan Pasal 487, dapat ditambah dengan 1/3 (satu per tiga), jika yang dihina atau difitnah adalah seorang pejabatyang sedang menjalankan tugasnya yang sah, merupakan delik aduan.

- Pasal 489 (1); Setiap Orang yang mengajukan pengaduan atau pemberitahuan palsu secara tertulis atau menyuruh orang lain menuliskan kepada pejabat yang berwenang tentang seseorang sehingga kehormatan atau nama baik orang tersebut diserang dipidana karena melakukan pengaduan fitnah; sementara pada ayat (2) Setiap Orang sebagaimana dimaksud pada ayat (1) dapat dijatuhi pidana tambahan berupa pencabutan hak sebagaimana dimaksud dalam Pasal 96 huruf a dan/atau huruf b, merupakan delik aduan

- Pasal 492; melakukan pencemaran atau pencemaran tertulis terhadap orang mati, merupakan delik aduan.

- $\quad$ Pasal 285 (1); menyiarkan suatu berita atau mengeluarkan pemberitahuan atau menyebarluaskan melalui sarana teknologi 
Jurnal Pembangunan Hukum Indonesia

Volume 2, Nomor 2, Tahun 2020
Program Studi Magister IImu Hukum Fakultas Hukum Universitas Diponegoro informasi yang mengakibatkan keonaran atau kerusuhan dalam masyarakat, padahal diketahui atau patut diduga bahwa berita atau pemberitahuantersebut adalah bohong.

- Pasal 285 (2); menyiarkan berita bohong atau pemberitahuan bohong yang mengakibatkan keonaran atau kerusuhan dalam masyarakat.

- Pasal 589; secara melawan hukum dengan maksud menguntungkan diri sendiri atau orang lain, menyiarkan kabar bohong menyebabkan naik atau turunnya harga Barang dagangan, dana, transaksi keuangan, atau Surat berharga.

\section{a. Perbandingan dengan Negara Lain}

Usaha dalam mewujudkan suatu Kebijakan formulasi hukum pidana, pembuat kebijakan (legislator) hendaknya melakukan kajian perbandingan dengan negara-negara lain. Menurut Rene David dan Brierley dalam Barda Nawawi Arief (Arief, 2003), manfaat dari perbandingan hukum adalah: (1) Berguna dalam penelitian hukum yang bersifat historis dan filosofis; (2) Penting untuk memahami lebih baik dan untuk mengembangkan hukum nasional kita sendiri; dan (3) Membantu dalam mengembangkan pemahaman terhadap bangsa-bangsa lain dan oleh karena itu memberikan sumbangan untuk menciptakan hubungan atau suasana yang baik bagi perkembangan internasional.

Pendapat Rene David dan Brierley tersebut menunjukkan bahwa perbandingan hukum selain berguna dalam penelitian hukum, juga dapat menjadi sarana untuk pengembangan hukum nasional dan mempererat kerjasama internasional. Adanya perbandingan dengan sistem hukum negara lain, sehingga kemudian akan diketahui persamaan dan perbedaannya, sehingga dapat dijadikan bahan pertimbangan atau masukan ke dalam sistem hukum nasional.

\section{(1).India (UU No. 21 tahun 2000 tentang Teknologi Informasi di India (The Information Technology Act No. 21 of 2000 in India)}

Delik ujaran kebencian sebagai akibat penyalahgunaan internet untuk terdapat pada Bab XI (Chapter XI) Pasal 66 A Undang-Undang No. 21 tahun 2000 tentang Teknologi Informasi (The Information Technology Act No. 21 of 2000 in India). Rumusan tersebut tampak bahwa negara India sudah mengakomodasi dan mengakui keberadaan internet sebagai salah satu media elektronik, walaupun tidak menyebutkannya secara eksplisit dalam rumusan pasal diatas.

Dengan adanya pengakuan dari media elektronik salah satunya adalah internet sebagai salah satu media yang dapat digunakan untuk mempublikasikan atau memindahkan atau menyebabkan terpublikasikannya berbagai materi atau bahan yang membangkitkan kebencian atau penghinaan atau jika efeknya ditujukan untuk merusak dan mendorong orang yang melakukan hal yang hampir sama bahkan melalukan hal besar yang bersifat kekacauan, konflik social, kekerasan, memiliki perhatian terhadap seluruh lingkungan yang relevan, untuk membaca, melihat atau 
Jurnal Pembangunan Hukum Indonesia

Volume 2, Nomor 2, Tahun 2020
Program Studi Magister Ilmu Hukum Fakultas Hukum Universitas Diponegoro mendengarkan materi yang berisi gabungan (materimateri sebelumnya) di dalamnya, maka hal ini dapat diartikan bahwa India tidak menggunakan paradigma yang berorientasi pada perbuatan secara fisik, melainkan telah menggunakan paradigma fungsional dalam memaknai perbuatan yang dapat dikriminalisasikan. Dalam UU ini di atur pertanggungjawaban korporasi secara tegas.

\section{(2). Australia (Racial and Religious Tolerance Act} 2001 Act No. 47/2001 Negara Bagian Victoria -

\section{Australia)}

UU Toleransi Ras dan Agama 7. Racial vilification unlawful (1) "A person must not, on the ground of the race of another person or class of persons, engage inconduct that incites hatred against, serious contempt for, or revulsion or severe ridicule of, that other person or class of persons". (2)"For the purposes of sub-section(1), conduct- (a) may be constituted by a single occasion orby a number of occasions over a period of time; and (b) may occur in or outside Victoria". Note: "engage in conduct" includes use of the internet or e-mail to publish or transmit statements or other material.

Pasal 7. Pembajakan rasial melanggar hukum (1) "Seseorang tidak boleh, atas dasar rasorang atau kelas orang lain, terlibat perilaku yang menghasut kebencian, serius penghinaan, atau jijik atau cemoohan berat,orang lain atau kelas orang. (2) "Untuk keperluan sub-bagian (1), perilaku— (a) dapat dibentuk oleh satu kesempatan atau oleh sejumlah kesempatan selama periode waktu; dan (b) dapat terjadi di dalam atau di luar Victoria". Catatan: "terlibat dalam perilaku" termasuk penggunaan internet atau e-mail untuk mempublikasikan atau mengirim pernyataan atau materi lain.

Act8. Religious vilification unlawful (1)"A person must not, on the ground of the religious belief or activity of another person or class of persons, engage in conduct that incites hatred against, serious contempt for, or revulsion or severe ridicule of, that other person or class of persons". Note: "engage in conduct" includes use of the internet or e-mail to publish or transmit statements or other material. (2)"For the purposes of sub-section (1), conduct- (a) may be constituted by a single occasion or by a number of occasions over a period oftime; and (b) may occur in or outside Victoria".

Pasal 8. Fitnah agama melanggar hukum (1) "Seseorang tidak boleh, atas dasar agama keyakinan atau aktivitas orang atau kelas lain orang, terlibat dalam perilaku yang memicu kebencian melawan, penghinaan serius, atau jijik atau cemoohan berat, orang atau kelas lain itu orang-orang". Catatan: "terlibat dalam perilaku" termasuk penggunaan internet atau e-mail untuk mempublikasikan atau mengirim pernyataan atau materi lain. (2)"Untuk keperluan sub-bagian (1), perilaku- (a) dapat dibentuk oleh satu kesempatan atau oleh sejumlah kesempatan selama periode waktu; dan (b) dapat terjadi di dalam atau di luar Victoria".

Act9. Motive and dominant ground irrelevant (1)"In determining whether a person has contravened 
Jurnal Pembangunan Hukum Indonesia

Volume 2, Nomor 2, Tahun 2020
Program Studi Magister Ilmu Hukum Fakultas Hukum Universitas Diponegoro section 7 or 8 , the person's motive in engaging in any conduct is irrelevant". (2) "In determining whether a person has contravened section 7 or 8 , it is irrelevant whether or not the race or religious belief or activity of another person or class of persons is the only or dominant ground for the conduct, so long as it is a substantial ground". Incorrect assumption as to race or religious belief or activity In determining whether a person has contravened section 7 or 8 , it is irrelevant whether or not the person made an assumption about the race or religious belief or activity of another person or class of persons that was incorrect at the time that the contravention is alleged to have taken place.

Pasal 9. Motif dan tanah dominan tidak relevan (1) "Dalam menentukan apakah seseorang telah melanggar bagian 7 atau 8, motif seseorang dalam terlibat perilaku apa pun tidak relevan". (2) "Dalam menentukan apakah seseorang telah melanggar bagian 7 atau 8 , tidak relevan apakah atau tidak ras atau keyakinan agama atau aktivitas orang lain orang atau kelas orang adalah satu-satunya atau dominan dasar untuk perilaku, selama itu adalah tanah substansial". Asumsi yang salah untuk ras atau keyakinan agama atau aktivitas dalam menentukan apakah seseorang telah melanggar bagian 7 atau 8 , tidak relevan apakah atau tidak orang membuat asumsi tentang perlombaan atau keyakinan agama atau aktivitas orang lain ataukelas orang yang salah pada saat itu pertentangan itu diduga terjadi.
Act11. Exceptions-public conduct "A person does not contravene section 7 or 8 if the person establishes that the person's conduct was engaged in reasonably and in good faith- (a) in the performance, exhibition or distribution of an artistic work; or (b) in the course of any statement, publication, discussion or debate made or held, or any other conduct engaged in, for- (i) any genuine academic, artistic, religious or scientific purpose; or (ii) any purpose that is in the public interest; or (c) in making or publishing a fair and accurate report of any event or matter of public".

Adapun terkait masalah-masalah pokok hukum pidana yang lain, yaitu maslaah pertanggungjawaban pidana, ternyata negara bagian Victoria - Australia juga telah mengantisipasi perkembangan mutakhir tentang adanya subjek tindak pidana yang berwujud badan hukum/korporasi. Hal ini dapat dilihat dari rumusan Pasal 24 Undang-Undang No. 47 Tahun 2001 tentang Toleransi Ras dan Agama.

\section{SIMPULAN}

Berdasarkan hasil penelitian yang diperoleh, dapat disimpulkan bahwa Kebijakan Hukum Pidana Dalam Pengaturan Dan Penanggulangan Ujaran Kebencian (Hate Speech) Di Media Sosial diantaranya telah ada dalam Kitab Undang-Undang Hukum Pidana sebagai induk aturan perundangundangan pidana materiil dan telah ada dalam undang-undang di luar KUHP. Undang-undang tersebut diantaranya UU Nomor 1 Tahun 1946; UU 
Jurnal Pembangunan Hukum Indonesia

Volume 2, Nomor 2, Tahun 2020
Program Studi Magister Ilmu Hukum Fakultas Hukum Universitas Diponegoro
Nomor 1/PNPS Tahun 1965; UU Nomor 40 Tahun 1999; UU Nomor 32 Tahun 2002; UU Nomor 40 Tahun 2008; UU Nomor 19 Tahun 2016. Undangundang tersebut memiliki banyak kelemahan yuridis yang mengakibatkan sistem pemidanaan tidak dapat bekerja dengan baik dan maksimal. KUHP menghendaki pengaturan penyebaran ujaran kebencian dengan mengaturnya sebagai pelanggaran atau kejahatan, namun undang-undang di luar KUHP tidak mencantumkan kualifikasi delik. Dari keenam undang-undang tersebut memiliki kelemahan/masalah yuridis yang sama. Kelemahan kelemahan yuridis terkait kejahatan korporasi di bidang ujaran kebencian ini tidak terdapat dalam tindak pidana yang diatur oleh undang-undang yang ada, namun kelemahannya terletak pada pertanggungjawaban pidana (PJP) korporasi, dan pada pidana yang dijatuhkan terhadap korporasi yang melakukan kejahatan korporasi di bidang ujaran kebencian. Misalnya masalah pertanggungjawaban pidana (PJP) korporasi di bidang ujaran kebencian, antara lain berupa tidak ada ketentuan kapan korporasi dapat dipertanggungjawabkan, sedangkan dari sisi sanksi pidana, apabila denda tidak dibayarkan tidak diatur masalah apa pidana pengganti denda yang dapat diberikan guna menggantikannya.

Formulasi hukum pidana dalam penanggulangan ujaran kebencian di masa yang akan datang terlihat lebih bagus dan lebih lengkap dari pada formulasi hukum pidana dalam penanggulangan ujaran kebencian di masa yang akan datang. Terlebih dalam Konsep KUHP yang mengatur hal apa saja yang dapat dipidana terkait ujaran kebencian, bentuk-bentuk ujaran kebencian di dalam dunia maya, kemudian kapan korporasi dapat dibebankan pertanggungjawaban pidana, siapa yang dapat dipertanggungjawabkan terkait kejahatan korporasi, adanya pengaturan tentang pidana pengganti denda apabila korporasi tidak mampu membayar denda, dan mengenai tindak pidana yang dilakukan korporasi di dalam penyebaran ujaran kebencian apabila tidak diatur oleh Konsep KUHP maka undang-undang khusus yang mengaturnya masih berlaku, hal ini adalah suatu langkah progresif yang ditunjukkan oleh sistem pemidanaan di masa yang akan datang dalam menanggulangi kejahatan penyebaran ujaran kebencian.

\section{DAFTAR PUSTAKA}

\section{BUKU}

Chazawi, Adami., \& Ferdian, Ardi. (2011). Tindak Pidana Informasi \& Transaksi Elektronik Penyerangan Terhadap Kepentingan Hukum Pemanfaatan Teknologi Informasi dan Transaksi Elektronik. Malang: Banyumedia Publishing.

Raharjo, A. (2002). Pemahaman Dan Upaya Upaya Pencegahan Berteknologi. Bandung: Citra Aditya Bakti.

Arief, Barda N . (2016). Kebijakan Formulasi Ketentuan Pidana Dalam Peraturan 
Jurnal Pembangunan Hukum Indonesia

Volume 2, Nomor 2, Tahun 2020
Program Studi Magister Ilmu Hukum Fakultas Hukum Universitas Diponegoro

Perundang-undangan. Semarang : Penerbit Marpaung, L. (2010). Tindak Pidana Terhadap

Pustaka Magister.

Kehormatan, Jakarta: Sinar Grafika.

Arief, Barda N. (2003). Perbandingan Hukum Pidana.

Jakarta: RajaGrafindo Persada.

Arief, Barda N. (2005). Beberapa Aspek Kebijakan

Penegakan dan Pengembangan Hukum

Pidana. Bandung: Citra Aditya Bakti.

Arief, Barda N. (2008). Delik Agama : Penghinaan

Tuhan (Blasphemy) di Indonesia dan

Perbandingan Berbagai Negara. Semarang:

Badan Penerbit Universitas Diponegoro.

Arief, Barda N. (2008). RUU KUHP Baru, Sebuah

Reskontrukturisasi/Rekonstruksi Sisterm

Hukum Pidana Indonesia. Semarang: Badan

Penerbit Universitas Diponegoro.

Elliot, Charlotte., Chuma, Wallace., El Gendi, Yosra.,

Marko, Davor., \& Patel, Alisha. (2016). Hate

Speech Key Concept paper, Media Conflict

and Demonstration. United Kingdom:

University of Leeds.

Grande, Irene S. (2006). Hate Crime, Comparative

Law Annotation, Groningen University.

Diantha, I Made Pasek. (2016). Metodologi Penelitian

Hukum Normatif dalam Justifikasi Teori

Hukum, Jakarta: Prenada Media Group.

Sitompul, J. (2012). Cyber space, Cyber crimes,

Cyberlaw Tinjaun Aspek Hukum Pidana.

Jakarta: PT. Tatanusa.

Mansur, Dikdik M. Arief ., \& Gultom, Elsatris. (2009).

Cyber Law: Aspek Hukum Teknologi Informasi.

Bandung: Refika Aditama.

\section{J URNAL \& ARTIKEL}

Ali, M. (2010). Pencemaran Nama Baik Melalui Sarana Informasi dan Transaksi Elektronik (Kajian Putusan MK No.2/PUU-VII/2009). Jurnal Konstitusi, Vol.7, (No.6, Desember 2010),pp. 15-18.

Arief, Barda N. (2005). Kebijakan Penanggulangan Cyber Crime dan Cyber Sex. Jurnal Law Reform, Vol. 1, (No.1), p.3.

Bleich, E. (2011). The Rise of Hate Speech and Hate Crime Laws in Liberal Democracies. J ournal of Ethnic and Migration Studies, Vol.37, Issue 6, pp.917-934.

Brown, A. (2017). Hate Speech Laws, Legitimacy, and Precaution: A Reply to James Weinstein. J ournal Constitutional Repository 2017, Vol 34, University of Minnesota Law School, p.21.

Dahri, M. 2017). Tindak Pidana Penodaan Agama di Indonesia; Tinjauan Pengaturan PerundangUndangan dan Konsep Hukum Islam. AtTafahum: J ournal of Islamic Law, Vol.1,(No. 2 Juli-Desember), p.36. 
Jurnal Pembangunan Hukum Indonesia

Volume 2, Nomor 2, Tahun 2020
Program Studi Magister Ilmu Hukum Fakultas Hukum Universitas Diponegoro
Goodall, K. (2013). Conceptualising 'Racism' in Criminal Law. Cambridge University Legal Studies J ournal, Vol. 33, (No 2 June), p.9

Jacobs, James B., \& Henry, Jessica S. (1996). The

Social Construction of Hate Crime Epidemic.

The Journal of Criminal Law \& Criminology, Vol.86, (No.2),p. 366.

Anam, M Choirul., \& Hafiz, Muhammad.(2015). Surat Edaran Kapolri Tentang Penanganan Ujaran Kebencian ( Hate Speech) dalam Kerangka Hak Asasi Manusia. Jurnal Keamanan Nasional, Vol.1, (No.3), pp.341-364.

Mangantibe, V. (2016). Ujaran Kebencian Dalam

Surat Edaran Kapolri Nomor : SE/6/X/2015 tentang Penanganan Ucapan Kebencian (Hate Speech). Lex Crimen,Vol.5, (No.1), pp. 159162.

Monica, Dona R. (2017). Upaya Kepolisian Dalam Penanggulan Tindak Pidana Penyebaran Hoax. Jurnal Poenale, Vol.5, (No.2), p.1023.

Nurdin, N. (2017). Delik Penodaan Agama Islam di Indonesia. International Journal Ihya' Ulum AlDin, Vol 19, (No 1), p.15.

Siddiq, Nur A. (2017). Penegakan Hukum Pidana dalam Penanggulangan Berita Palsu (Hoax) Menurut Undang-Undang Nomor 11 Tahun 2008 Yang Telah Dirubah Menjadi UndangUndang Nomor 19 Tahun 2016 tentang Informasi dan Transaksi Elektronik. Lex Et Sociatatis, Vol.5, (No.10), pp.26-32.
Nahak, S. (2017). Hukum Tindak Pidana Mayantara (Cybercrime) dalam Prespektif Akademik. J urnal Hukum Prasada, Vol 4, (No.1, Maret 2017), p.1-11.

Supanto. (2016). Perkembangan Kejahatan Teknologi Informasi (Cyber Crime) dan Antisipasi dengan Penal Policy. Yustisia; Jurnal Hukum, Vol.5, (No. 1, Januari-April), pp.52-70.

Pejchal, V. (2018). Hate Speech Regulation in PostCommunist Countries: Migrant Crises in the Czech and Slovak Republics. International Journal of Crime, Juctice and Social Democracy, Vol 7, (No. 2), pp.58-74.

Tampi, B. (2016). Kontroversi Pencantuman Pasal Penghinaan Terhadap Presiden dan Wakil Presiden dalam KUHP yang Akan Datang. J urnal IImu Hukum,Vol.III, (No.9),pp. 25-27.

\section{SUMBER ONLINE}

Amelia, R. (2016). Kejahatan Cyber di Jakarta Sepanjang 2016 Mencapai 1207 Kasus. Retrieved from https://news.detik.com/ berita/3384545/kejahatan-cyber-dijakartasepanjang-2016-mencapai-1207-kasus. 